\title{
Hukkakauran siementen itävyyden säilyminen kokoviljasäilörehussa
}

\author{
${ }^{1,5)}$ Saarisalo, E., ${ }^{1)}$ Heikkilä, T., ${ }^{2)}$ Jalli, H., ${ }^{3)}$ Poikulainen, J., ${ }^{3)}$ Köylijärvi, S. ja ${ }^{4)}$ Jaakkola, S. \\ ${ }^{1)}$ MTT, Kotieläintuotannon tutkimus, 31600 Jokioinen, etunimi.sukunimi@mtt.fi \\ ${ }^{2)}$ MTT, Kasvintuotannon tutkimus, 31600 Jokioinen \\ ${ }^{3)}$ Elintarviketurvallisuusvirasto, Evira, PL 111,32201 Loimaa, etunimi.sukunimi@evira.fi \\ ${ }^{4)}$ Helsingin yliopisto, Kotieläintieteen laitos, 00014 Helsingin yliopisto, etunimi.sukunimi@ helsinki.fi \\ ${ }^{5)}$ Nykyinen osoite: MMM, Elintarvike- ja terveysosasto, PL 30, 00023 Valtioneuvosto
}

Hukkakaura on lakisääteisesti torjuttava rikkakasvi, joka on ensisijaisesti torjuttava kitkemällä tai kemiallisesti. Jos torjunta epäonnistuu, viranomainen voi antaa hävittämismääräyksen. Vaihtoehtoja ovat olleet niitetyn kasvuston toimittaminen kaatopaikalle tai polttaminen. Kasvimassaa on usein niin paljon, että kaatopaikat eivät ota sitä vastaan. Kostea kasvusto ei myöskään pala herkästi. Peltoalasta ei näissä tapauksissa makseta tukia, koska sadon korjuuvelvoite ei täyty. Tutkimuksessa selvitettiin, miten hukkauran itävyys kehittyy kasvukauden aikana ja häviääkö itävyys kokoviljasäilönnässä. Jos itävyys häviää ja viranomainen sallii saastuneen kasvuston korjuun kokoviljasäilörehuksi, vältetään tukien menetyksistä ja kasvuston hävittämisestä aiheutuvat tappiot.

Hukkakauran saastuttamalta ohrapellolta kerättiin vuosina 2005 ja 2006 hukkakauran siemeniä röyhylle tulosta alkaen kuusi kertaa viikon välein. Samalta pellolta kerättiin ohraa, joka silputtiin kokoviljasäilörehun raaka-aineeksi. Säilöntäainekäsittelyjä olivat painorehu (PR), muurahaishappo 2, 4 ja 6 1/t (MH2, MH4 ja MH6) sekä maitohappobakteerivalmiste (Lactofast, 10 ${ }^{6}$ pmy/g, Y). Käsitellyn silpun joukkoon sekoitettiin hukkakauran siemeniä ja massa säilöttiin koesiiloihin. Siilot avattiin ja rehusta eroteltiin hukkakauran jyvät itävyysanalyysiin 3 viikon ja 3 sekä 6 kuukauden säilönnän jälkeen. Lisäksi vuonna 2006 tutkittiin hukkakauran siementen itävyyttä pyöröpaaleissa. Siemenet laitettiin läpäisevissä pusseissa paalien sisään ja pinnalle. Kokeessa oli kaksi korjuuaikaa, kolme säilöntäkäsittelyä (PR, MH ja Y) ja kaksi säilöntäaikaa (3 vk ja 3 kk).

Koevuodet olivat sääolosuhteiltaan erilaiset. Molempina vuosina jo kaksi viikkoa röyhylle tulon jälkeen ensimmäiset hukkakauran siemenet olivat itämiskykyisiä. Tuleentumisen myötä itävyys lisääntyi lukuun ottamatta sateisen kesän 2005 viimeistä kertaa. Silloin tuleentuneita siemeniä oli varissut ja mukana oli runsaasti myöhemmin kehittyneiden sivuversojen siemeniä. Kuivana kesänä 2006 hukkakaurassa sivuversoja kehittyi selväsi vähemmän ja tuleentuminen oli tasaisempaa.

Vuonna 2005 viimeisen korjuukerran MH2- ja MH4-rehusta todettiin yksi itämiskykyinen hukkakauran siemen kolmen viikon säilönnän jälkeen. Vuonna 2006 viidennen korjuukerran MH2rehussa oli kaksi itämiskykyistä siementä kolmen viikon säilönnän jälkeen. Sen sijaan kuudennen korjuukerran rehuissa oli runsaasti itäviä siemeniä muissa kuin MH4- ja MH6-rehuissa. Molempina vuosina itävyys hävisi kolmen kuukauden säilönnässä kaikissa rehuissa. Paalikokeessa kolmen viikon jälkeen ensimmäisen korjuukerran paaleissa hukkakauran itävyys oli hävinnyt. Sen sijaan toisen korjuukerran paalien pinnassa oli säilöntäainekäsittelystä riippumatta runsaasti itämiskykyisiä hukkakauran siemeniä. Vain paalin sisällä olleiden siementen itävyys hävisi. Kolmen kuukauden jälkeen paaleissa olleiden siementen itävyys oli hävinnyt. Rehujen käymisanalyysien perusteella säilöntäaineen riittävä käyttö varmistaa pH:n laskun ja hyvän käymislaadun sekä edistää itävyyden häviämistä.

Jos hukkakaura havaitaan torjunnan kannalta liian myöhään, kasvusto voidaan tutkimuksen perusteella korjata kokoviljasäilörehuksi. Hukkakauran siemenet kehittyvät nopeasti ja tuleentuneet siemenet varisevat herkästi, joten korjuu on tehtävä kahden viikon sisällä röyhylle tulosta. Säilöntäajan tulee olla vähintään kolme kuukautta. Hukkakaura tuottaa runsaasti versoja, joten kasvusto on niiton jälkeen käsiteltävä glyfosaattivalmisteella tai muokattava torjuntaohjelman mukaan.

Asiasanat

Hukkakaura, Avena fatua, säilörehu, kokovilja, itävyys, muurahaishappo, pH. 


\section{Johdanto}

Elintarviketurvallisuusviraston (Evira) mukaan hukkakauraa esiintyy noin 14 prosentilla Suomen peltoalasta. Laki hukkakauran torjunnasta (185/02) kieltää hukkakauraisen kasvimateriaalin, kotieläinten lannan ja maa-aineksen kuljettamisen, säilyttämisen tai käsittelyn siten, että siitä voi aiheutua hukkakauran leviämisen vaara. Maa- ja metsätalousministeriön hukkakauran torjunnasta annetussa asetuksessa (326/02) on tarkemmat säännöt hukkakauran torjunnasta ja leviämisen estämisestä. Lain täytäntöönpanosta ja säännösten noudattamisen valvonnasta vastaa Evira.

Hukkakaura on ensisijaisesti torjuttava käsin kitkemällä tai kemiallisesti. Ongelmaksi jäävät lohkot, joilla torjunta on epäonnistunut. Hukkakaura on ongelma myös luomutuotannossa, koska kemiallista torjuntaa ei sallita eikä käsin kitkentä aina ole mahdollista. Jos hukkakauran torjunta on epäonnistunut, viranomaiset voivat tarkastuksen suoritettuaan antaa hävittämismääräyksen. Vaihtoehdoksi jää kauppakelvottoman sadon tuhoaminen joko toimittamalla niitetty kasvusto kaatopaikalle tai polttamalla. Ongelmaksi muodostuu kuitenkin se, että jo muutaman hehtaarin alalta kertyvä kasvimassa on niin suuri, että kaatopaikat eivät ota sitä vastaan. Kaatopaikalla hukkakaura aiheuttaa leviämisriskin. Kostea kasvusto ei myöskään pala herkästi. Peltoalasta ei näissä tapauksissa makseta tukia, koska sadon korjuuvelvoite ei täyty. Ratkaisu voisi olla kasvuston korjuu kukinnan jälkeen kokoviljasäilörehuksi. Korjuuvelvoitteen toteutuessa vältetään tukien menetyksistä ja kasvuston hävittämisestä aiheutuvat tappiot.

Kokoviljan korjuu säilörehuksi voi vähentää hukkakauraa (Harker ym. 2003). Säilörehussa olevan hukkakauran siemenen itävyyttä ja itävyyteen vaikuttavia tekijöitä ei kuitenkaan juuri tunneta, eikä aiheesta ole kotimaisia tutkimustuloksia. Blackshaw ja Rode (1991) selvittivät rikkakasvien itävyyttä sekä säilönnän että pötsiuiton jälkeen. Heidän tutkimuksensa perusteella säilönnällä olisi mahdollista tuhota hukkakauran itävyys. Kanadalaiset kokeet eivät kuitenkaan anna tarkkaa kuvaa itävyyden säilymisestä eri olosuhteissa eikä niiden varaan voi perustaa viranomaisten suosituksia.

Vuonna 2005 alkaneessa, kolmivuotisessa hankkeessa hukkakauran siementen itävyyden tuhoutumista säilörehussa selvitettiin kokeissa, joissa hukkakauraista kasvustoa korjattiin ja säilöttiin kokoviljasäilörehuksi minisiiloissa. Tutkimuksen tavoitteena oli selvittää olosuhteet, joissa rehussa oleva hukkakauran siemen varmasti menettää itävyytensä. Kokeissa selvitettiin miten hukkakauran kehitysvaihe, säilöntäainekäsittely ja säilöntäaika vaikuttivat itävyyden säilymiseen. Tavoitteena oli määritellä säilöntämenetelmä, jolla itävyys häviää. Kokeet toistettiin kahtena vuotena, jotta saatiin vaihtelua kasvu- ja säilöntäolosuhteisiin.

Käytännössä hukkakauran saastuttama viljakasvusto korjattaisiin usein pyöröpaaleina. Kasvuston kuiva-ainepitoisuus on melko pieni siinä vaiheessa, kun hukkakaurainen kasvusto on korjattava. Pyöröpaalausmenetelmää ei kuitenkaan suositella märän rehun tekoon. Kasvusto on yleensä esikuivattava, jotta rehun laatu- ja puristenesteongelmilta vältytään. Tarkkuussilputtuun rehuun verrattuna paalirehun silppu on selvästi pidempää. Nämä kaikki tekijät vaikuttavat rehun tiivistymiseen, käymisprosessiin ja pH:n tasoon. Hankkeen toisena kesänä tutkittiinkin pyöröpaalimenetelmän soveltuvuus hukkakaurakasvuston korjuuseen ja hukkakauran itävyyden häviäminen paalirehussa.

\section{Aineisto ja menetelmät}

Raaka-aine ja käsittelyt. Säilöntäkokeet tehtiin MTT:1lä Jokioisilla vuosina 2005 ja 2006. Kokeissa käytetty hukkakaura saatiin yksityisen maatilan ohrapellolta. Hukkakauran siemenet ja rehun raakaaine kerättiin hukkakauran röyhylle tulosta alkaen kuusi kertaa viikon välein (kehitysasteet 0 - 5) (taulukko 1). Näytteistä määritettiin hukkakauran siementen itävyys. Samalta pellolta kerättiin ohraa, joka silputtiin kokoviljasäilörehun raaka-aineeksi. Säilöntäainekäsittelyjä oli viisi: Painorehu (PR) ilman säilöntäainetta, Muurahaishappo 2, 4 ja 6 1/t (MH2, MH4 ja MH6) sekä biologinen maitohappobakteerivalmiste (Lactofast, Kemira GrowHow, Y) ohjeenmukaisesti $10^{6}$ pmy/g. Rehut säilöttiin pieniin koesiiloihin (120 ml). Ennen siilojen täyttöä säilöntäaineella käsitellyn kokoviljasilpun joukkoon sekoitettiin hukkakauran siemeniä $200 \mathrm{kpl} / \mathrm{siil}$. Siilot avattiin ja rehusta eroteltiin hukkakauran siemenet itävyysanalyysiin (100 kpl/siilo) kolmen viikon ja kolmen sekä kuuden kuukauden säilönnän jälkeen.

Vuoden 2006 pyöröpaalikokeeseen siemenet kerättiin samalta alalta kuin minisiilokokeeseen. Ohra oli eri lohkolta puhdasta ohrakasvustoa (Annabell, 2-tahoinen, kylvetty 9.5.), joka oli samassa kehitysvaiheessa kuin hukkakaurainen pelto (Barke, 2-tahoinen, kylvetty 8.5.). Paalit tehtiin kahden viikon välein hukkakauran kehitysasteissa 2 ja 4 . Ohrakasvusto kaadettiin niittomurskaimella ja paalattiin silppuavalla, kiinteäkammioisella pyöröpaalaimella. Paaleja tehtiin neljä rinnakkaista käyttäen 
kolmea säilöntäainekäsittelyä, jotka olivat PR, happosäilöntäaine 6 1/tn (AIV 2 Plus, Kemira GrowHow, MH) ja biologinen säilöntäaine $10^{6} \mathrm{pmy} / \mathrm{g}$ (Lactofast, Y). Hukkakauran siemenet sijoitettiin paaleihin läpäisevissä pusseissa (100 siementä/pussi), viisi pussia pintaan (ylä- ja alapäätyyn, pyöreälle kehälle lähelle kumpaakin päätyä sekä keskelle) käärintäverkon alle sekä kaksi kairattuihin reikiin noin $60 \mathrm{~cm}$ syvyyteen. Kairatut reiät täytettiin rehumassalla ja tarkoitukseen valmistetuilla muovitulpilla. Paalit käärittiin kuudella kerroksella käärintämuovia. Paalien säilöntäajat olivat kolme viikkoa ja kolme kuukautta.

Näytteenotto ja analyysit. Hukkakauran siemenistä otettiin edustava näyte itävyysanalyysiä varten. Näytteestä tehtiin itävyysmääritys (3 x $100 \mathrm{kpl})$ Evirassa Loimaalla. Kokoviljaraaka-aineesta otettiin näyte silppuamisen jälkeen. Näytteestä määritettiin kuiva-aine, tuhka, neutraalidetergenttikuitu (NDF), N, liukoinen N, sokeri, puskurikapasiteetti ja in vitro -sulavuus sellulaasimenetelmällä. Lisäksi säilöntäaineella käsitellystä raaka-aineesta määritettiin heti siilojen täytön jälkeen kuiva-aine ja pH. Kolme siiloa säilöntäainekäsittelyä kohti avattiin 21, 84 ja 168 vrk säilönnän jälkeen. Rehusta eroteltiin vähintään 100 kpl hukkakauran siemeniä, joista tehtiin itävyysmääritys Evirassa. Koska kahdella ensimmäisellä kerralla säilötyissä hukkakauran siemenissä ei ollut yhtään itäviä, näistä ei siemeniä erotettu.

Pyöröpaalikokeessa avattiin kolmen viikon ja kolmen kuukauden säilönnän jälkeen kaksi paalia säilöntäainekäsittelyä kohti. Paaleista kerättiin pois hukkakauraa sisältävät pussit ja samalla kairattiin analyysinäytteet. Hukkakauran siementen itävyys määritettiin. Säilörehunäytteistä määritettiin kuiva-aine, N, tärkkelys, pH, maitohappo, VFA, etanoli, pelkistävät sokerit, ammonium $\mathrm{N}$ ja muurahaishappo.

Tilastollinen testaus. Rehujen koostumustietojen testauksessa käytettiin varianssianalyysiä (SAS GLM). Testattavina kontrasteina olivat minisiilokokeessa säilöntäainekäsittelyt (PR vs. säilöntäaineet, MH vs. Y, MH:n lineaarinen ja MH:n toisen asteen vaikutus) ja säilöntäaika (3 viikkoa vs. 3 ja 6 kuukautta, 3 kuukautta vs. 6 kuukautta). Lisäksi testattiin päävaikutusten väliset yhdysvaikutukset.

\section{Tulokset ja niiden tarkastelu}

Koevuodet olivat sääolosuhteiltaan varsin erilaiset. Vuonna 2005 ensimmäisen ja viimeisen näytteenottokerran välillä lämpösumma lisääntyi 599 asteesta 980 asteeseen ja vettä satoi $197 \mathrm{~mm}$. Vuonna 2006 lämpösumma lisääntyi 575 asteesta 1022 asteeseen ja vettä satoi vain $24 \mathrm{~mm}$. Sateisena kesänä 2005, kun kosteutta oli riittävästi, aikaisessa vaiheessa niitetyssä kasvustossa oli runsaasti hukkakauran jälkikasvua.

Kasvukauden aikana Molempina vuosina ensimmäiset hukkakauran siemenet olivat itämiskykyisiä jo kaksi viikkoa röyhylle tulon jälkeen (kehitysaste 2). Tuleentumisen myötä itävyys lisääntyi lukuun ottamatta vuoden 2005 viimeistä kertaa, jolloin tuleentuneita siemeniä oli varissut ja mukana oli runsaasti myöhemmin kehittyneiden sivuversojen siemeniä.

Vuoden 2006 kuivana kesänä sivuversoja kehittyi selvästi vähemmän ja hukkakauran tuleentuminen oli tasaisempaa. Toiseksi viimeisen korjuukerran alempi itävyys johtunee siitä, että näytteenottokohdassa oli erittäin tiheä ja kitukasvuinen hukkakaurakasvusto. Kuivuus esti hukkakauran kasvua niin, että sen havaitseminen ohrakasvustosta oli vaikeaa.

Vuosien välinen ero näkyi myös minisiilokokeiden kokoviljasäilörehun raaka-aineen koostumuksessa (taulukko 1). Kasvuston kehittyessä rehun kuiva-ainepitoisuus lisääntyi molempina vuosina, mutta vuonna 2006 kuiva-ainepitoisuus oli selvästi suurempi viimeisinä korjuukertoina. Vuonna 2005 viidennen korjuukerran raaka-aineen suuri kosteuspitoisuus johtui osittain sateesta. Raaka-aineen sokeripitoisuus oli suurimmillaan viikko röyhylle tulosta, jonka jälkeen se pieneni. Tuleentumisen edistyessä tärkkelyspitoisuus suureni ja NDF-pitoisuus sekä puskurikapasiteetti pienenivät. Vuonna 2006 sokeripitoisuus oli selvästi suurempi ja tärkkelyspitoisuus pienempi kuin vuonna 2005.

Säilönnän jälkeen Kumpanakaan koevuotena kolmen ja kuuden kuukauden säilönnän jälkeen siilorehuissa ei ollut yhtään itävää siementä. Sen sijaan kolmen viikon säilöntäaika ei riittänyt tuhoamaan itävyyttä (taulukko 1). Itävyys säilyi siemenissä, jotka oli kerätty neljä tai viisi viikkoa hukkakauran röyhylle tulon jälkeen (viides ja kuudes korjuukerta). Vuonna 2005 kuudennen korjuukerran MH2 ja MH4 rehuista todettiin yksi itämiskykyinen hukkakauran siemen kolmen viikon säilönnän jälkeen. Vuonna 2006 viidennen kerran $\mathrm{MH} 2$ rehussa oli kaksi itämiskykyistä siementä. Sen sijaan kuudennen korjuukerran rehuissa oli runsaasti itäviä siemeniä PR, MH2 ja Y rehuissa. Vuonna 2005 kuudennen korjuukerran rehujen (PR, 
MH2, MH4, MH6 ja Y) pH oli kolme viikkoa säilönnän jälkeen 4,73; 4,87; 4,77; 4,23 ja 4,03, kun vuonna 2006 pH oli vastaavasti 5,46; 5,10; 4,83; 4,35 ja 4,25. Itävyys säilyi yleensä rehuissa, joissa oli hieman korkeampi pH kuin muissa rehuissa. Tämä ei kuitenkaan pätenyt vuoden 2006 Y-rehuun, jonka pH oli muita matalampi $(4,25)$ ja rehusta löytyi silti itäviä siemeniä. Kolmen kuukauden jälkeen itäviä siemeniä ei enää todettu. Tällöin PR ja MH2 rehun $\mathrm{pH}$ oli laskenut ja Y rehun $\mathrm{pH}$ oli pysynyt lähes samana.

Paalikokeessa vuonna 2006 ensimmäinen korjuu tehtiin kaksi viikkoa hukkakauran röyhylle tulon jälkeen. Tällöin paaleihin sijoitettujen hukkakauran siementen itävyys oli hävinnyt jo kolmen viikon kuluttua säilönnästä (taulukko 2). Myöskään kolmen kuukauden säilöntäajan jälkeen ei todettu itäviä siemeniä. Toisen korjuukerran paaleihin sijoitettiin hukkakauran siemeniä, jotka oli kerätty neljä viikkoa röyhylle tulon jälkeen. Kolmen viikon säilönnän jälkeen paalien pintaosissa olleissa siemenissä oli runsaasti itämiskykyisiä hukkakauran siemeniä säilöntäainekäsittelystä riippumatta. Sen sijaan kolmen kuukauden jälkeen paaleissa ei enää ollut itäviä siemeniä.

Tulokset osoittavat, että itävyyden säilymiseen vaikuttaa hukkakauran siemenen ominaisuuksien (kehitysaste) lisäksi rehun käymisprosessissa syntyvät olosuhteet. Viljakasvuston kehitysasteen lisäksi säilöntäainekäsittely ja säilöntäaika vaikuttivat kokoviljasäilörehun koostumukseen ja käymislaatuun. Hukkakauran siementen itävyys säilyi rehuissa, joiden kuiva-ainepitoisuus oli yli $450 \mathrm{~g} / \mathrm{kg}$. Itävyys kuitenkin hävisi myös kuivissa rehuissa, kun säilöntäaika oli tarpeeksi pitkä. Blackshawn ja Roden (1991) tutkimuksessa kokoviljasäilörehun kuiva-ainepitoisuus oli 330 ja $360 \mathrm{~g} / \mathrm{kg}$ ja itävyys hävisi säilöntäajan ollessa kahdeksan viikkoa. Hukkakauran leviämisen estämiseksi saastuneen kasvuston korjuu kokoviljasäilörehuksi on tehtävä aikaisemmin kuin normaalissa taikinatuleentumisvaiheessa (Jaakkola ym. 2002). Aikainen korjuu on tärkeää myös hukkakauran siementen varisemisen välttämiseksi (Harker ym. 2003).

Kuvissa 1 ja 2 on esitetty minisiilorehujen koostumustietoja kuuden kuukauden säilönnän jälkeen. Rehut olivat pääosin käymislaadultaan hyviä. Virhekäymistä ei esiintynyt. Painorehussa ammoniumtypen osuus oli kuitenkin selvästi suurempi kuin muissa rehuissa, eikä rehun laatu vastannut kaikissa tapauksissa hyvälaatuisen rehun vaatimuksia. Kasvuston kehittyessä vesipitoisuuden väheneminen rajoitti maitohappokäymistä ja myös käymiseen tarvittavan sokerin määrä väheni. Toisaalta samanaikaisesti pienenevä puskurikapasiteetti edistää pH:n laskua. Happamuuteen vaikutti myös säilöntäaineen käyttö. Muurahaishapon suuri annostus esti luontaista käymistä ja maitohapon muodostumista. Tästä johtuivat myös happorehujen erittäin suuret sokeripitoisuudet.

Ilman säilöntäainetta tehtyjen paalirehujen käymislaatu oli myös heikompi kuin säilöntäaineella käsiteltyjen rehujen (taulukko 2). Painorehuissa oli enemmän ammoniumtyppeä ja voihappoa kuin muissa rehuissa.

\section{Johtopäätökset}

Tulosten perusteella hukkakauran saastuttaman kasvuston voi korjata kokoviljasäilörehuksi, jos hukkakaura havaitaan viljakasvustossa niin myöhään, ettei kemiallinen torjunta ole mahdollista ja hukkakauraa on liikaa kitkettäväksi. Korjuu on tehtävä kahden viikon sisällä röyhylle tulosta, koska hukkakauran siemenet kehittyvät nopeasti itämiskykyisiksi ja tuleentuneet siemenet varisevat herkästi. Säilöntäajan tulee olla vähintään kolme kuukautta, jotta siementen itävyys tuhoutuu. Säilöntäaineen käyttö parantaa rehun käymislaatua. Säilöntäohjeiden noudattaminen on erittäin tärkeää hukkakauran leviämisen estämiseksi. Hukkakaura tuottaa runsaasti versoja, joten kasvusto on niiton jälkeen käsiteltävä glyfosaattivalmisteella tai muokattava torjuntaohjelman mukaan

\section{Kirjallisuus}

Blackshaw, R. E. \& Rode, L. M. 1991. Effect of ensiling and rumen digestion by cattle on weed seed viability. Weed Science, 39: 104-108.

Eviran tietoa hukkakaurasta (25.11.2007) www.evira.fi/portal/fi/kasvintuotanto_ja_rehut/siemenet/hukkakaura/ Harker, K.N., Kirkland, K.J., Baron, V.S. \& Clayton, G.W. 2003. Early-harvest barley (Hordeum vulgare) silage reduces wild oat (Avena fatua) densities under zero tillage. Weed Technology 17, 102-110.

Jaakkola, S., Saarisalo, E., Heikkilä, T. \& Huhtanen, P. 2002. Ohra ja kevätvehnä kokoviljasäilörehuna lypsylehmien ruokinnassa. Maataloustieteen Päivät 2002: Kotieläintiede. Maaseutukeskusten Liiton julkaisuja 977. p. 151-155. 
Taulukko 1. Kokoviljasäilörehun raaka-aineen koostumus ja hukkakauran siementen itävyys ennen säilöntää sekä itävyys ja rehun pH kolmen viikon säilönnän jälkeen. Kolmen ja kuuden kuukauden säilönnän jälkeen hukkakauran siemenet eivät itäneet.

\begin{tabular}{|c|c|c|c|c|c|c|c|c|c|c|c|}
\hline \multirow{2}{*}{$\begin{array}{l}\text { Kehi- } \\
\text { tysaste } \\
\text { ja pvm }\end{array}$} & \multirow{2}{*}{$\begin{array}{c}\text { Kuiva- } \\
\text { aine, } \\
\text { g/kg }\end{array}$} & \multirow{2}{*}{$\begin{array}{l}\text { Sokeri } \\
\end{array}$} & \multirow{2}{*}{$\begin{array}{c}\text { Tärkkelys } \\
\text { g/kg ka }\end{array}$} & \multirow[t]{2}{*}{ NDF } & \multirow{2}{*}{$\begin{array}{c}\text { Puskuri- } \\
\text { kapasit., } \\
\text { mEkv/ } \\
\text { kg ka }\end{array}$} & \multirow{2}{*}{$\begin{array}{c}\text { Hukka- } \\
\text { kauran } \\
\text { siementen } \\
\text { itävyys,\% }\end{array}$} & \multicolumn{5}{|c|}{ Itäviä 3 vk säilönnästä, n=300/rehun pH } \\
\hline & & & & & & & PR & MH2 & MH4 & MH6 & $\mathbf{Y}$ \\
\hline \multicolumn{12}{|c|}{ Vuosi 2005} \\
\hline 0) 14.7 . & 252 & 159 & 41 & 530 & 449 & 0 & & & & & \\
\hline 1) 21.7 . & 270 & 189 & 58 & 489 & 368 & 0 & & & & & \\
\hline 2) 28.7 . & 324 & 131 & 209 & 440 & 321 & 16 & $0 / 4,48$ & $0 / 4,56$ & $0 / 4,68$ & $0 / 4,13$ & $0 / 3,84$ \\
\hline 3) 4.8 . & 385 & 91 & 321 & 403 & 253 & 30 & $0 / 4,56$ & $0 / 5,01$ & $0 / 4,53$ & $0 / 4,24$ & $0 / 3,90$ \\
\hline 4) 11.8 . & 326 & 51 & 369 & 423 & 194 & 74 & $0 / 4,08$ & $0 / 4,33$ & $0 / 4,35$ & $0 / 3,90$ & $0 / 3,85$ \\
\hline 5) 18.8 . & 468 & 39 & 378 & 417 & 177 & 46 & $0 / 4,73$ & $1 / 4,87$ & $1 / 4,77$ & $0 / 4,23$ & $0 / 4,03$ \\
\hline \multicolumn{12}{|c|}{ Vuosi 2006} \\
\hline 0) 6.7 . & 266 & 230 & 19 & 520 & 361 & 0 & & & & & \\
\hline 1) 12.7 . & 288 & 325 & 25 & 456 & 331 & 0 & & & & & \\
\hline 2) 19.7 . & 356 & 260 & 139 & 416 & 254 & 57 & $0 / 4,01$ & $0 / 4,07$ & $0 / 4,53$ & $0 / 4,22$ & $0 / 3,92$ \\
\hline 3) 26.7 . & 402 & 169 & 253 & 421 & 256 & 92 & $0 / 4,11$ & $0 / 4,28$ & $0 / 4,48$ & $0 / 4,26$ & $0 / 3,92$ \\
\hline 4) 1.8 . & 466 & 95 & 291 & 408 & 236 & 66 & $0 / 4,52$ & $2 / 5,19$ & $0 / 4,62$ & $0 / 4,32$ & $0 / 3,95$ \\
\hline 5) 9.8 . & 640 & 51 & 323 & 440 & 221 & 90 & $225 / 5,46$ & $50 / 5,10$ & $0 / 4,83$ & $0 / 4,35$ & $93 / 4,25$ \\
\hline
\end{tabular}

$\mathrm{NDF}=$ neutraalidetergenttikuitu, Säilöntäaineet: $\mathrm{PR}=$ ilman säilöntäainetta, $\mathrm{MH}=$ muurahaishappo, 2, 4 ja 6 1/t, $\mathrm{Y}=$ maitohappobakteeriymppi (Lactofast).

Taulukko 2. Paalirehujen koostumus ja säilönnällinen laatu sekä itävien hukkakauran siemenien määrä yhteensä (2 paalia per säilöntäainekäsittely). Rehut on tehty 2 ja 4 viikkoa hukkakauran röyhylle tulosta (=kehitysaste).

\begin{tabular}{|c|c|c|c|c|c|c|c|c|c|c|}
\hline \multirow{2}{*}{$\begin{array}{c}\text { Kehitys- } \\
\text { aste, } \\
\text { vk }\end{array}$} & \multirow{2}{*}{$\begin{array}{c}\text { Säilöntä- } \\
\text { aika, } \\
\text { vk }\end{array}$} & \multirow{2}{*}{$\begin{array}{l}\text { Säilöntä- } \\
\text { aine }\end{array}$} & \multirow{2}{*}{$\begin{array}{l}\text { Kuiva- } \\
\text { aine, } \\
\text { g/kg }\end{array}$} & \multirow[t]{2}{*}{ pH } & Sokeri & $\begin{array}{l}\text { Tärk- } \\
\text { kelys }\end{array}$ & $\begin{array}{l}\text { Maito- } \\
\text { happo }\end{array}$ & $\begin{array}{c}\text { Voi- } \\
\text { happo }\end{array}$ & \multirow{2}{*}{$\begin{array}{l}\text { Ammoni- } \\
\operatorname{um~N}, \\
\operatorname{g} / \mathbf{k g ~ N}\end{array}$} & \multirow{2}{*}{$\begin{array}{c}\text { Itäviä } \\
\text { siemeniä, } \\
\text { kpl }\end{array}$} \\
\hline & & & & & \multicolumn{4}{|c|}{$\mathrm{g} / \mathrm{kg} \mathrm{ka}$} & & \\
\hline 2 & 3 & PR & 322 & 5,00 & 176 & 107 & 26 & 0,84 & 71 & 0 \\
\hline 2 & 3 & $\mathbf{Y}$ & 346 & 3,95 & 202 & 106 & 71 & 0,28 & 17 & 0 \\
\hline 2 & 3 & MH & 351 & 4,17 & 260 & 110 & 8 & 0,32 & 33 & 0 \\
\hline 4 & 3 & PR & 431 & 4,36 & 48 & 274 & 37 & 0,12 & 19 & 158 \\
\hline 4 & 3 & $\mathbf{Y}$ & 413 & 3,94 & 49 & 286 & 59 & 0,12 & 9 & 89 \\
\hline 4 & 3 & MH & 427 & 4,32 & 105 & 268 & 4 & 0,08 & 20 & 153 \\
\hline 2 & 12 & PR & 321 & 4,59 & 146 & 90 & 37 & 3,40 & 84 & 0 \\
\hline 2 & 12 & $\mathbf{Y}$ & 337 & 3,91 & 186 & 108 & 81 & 0,27 & 26 & 0 \\
\hline 2 & 12 & MH & 354 & 4,12 & 240 & 92 & 16 & 0,80 & 52 & 0 \\
\hline 4 & 12 & PR & 414 & 4,36 & 48 & 249 & 36 & 1,00 & 38 & 0 \\
\hline 4 & 12 & $\mathbf{Y}$ & 397 & 3,95 & 45 & 250 & 65 & 0,21 & 22 & 0 \\
\hline 4 & 12 & MH & 400 & 4,22 & 124 & 245 & 8 & 0,18 & 48 & 0 \\
\hline
\end{tabular}

$\mathrm{PR}=$ ilman säilöntäainetta, $\mathrm{Y}=$ maitohappobakteeriymppi (Lactofast), $\mathrm{MH}$ = muurahaishappopohjainen säilöntäaine (AIV 2 Plus, 6 1/t). 

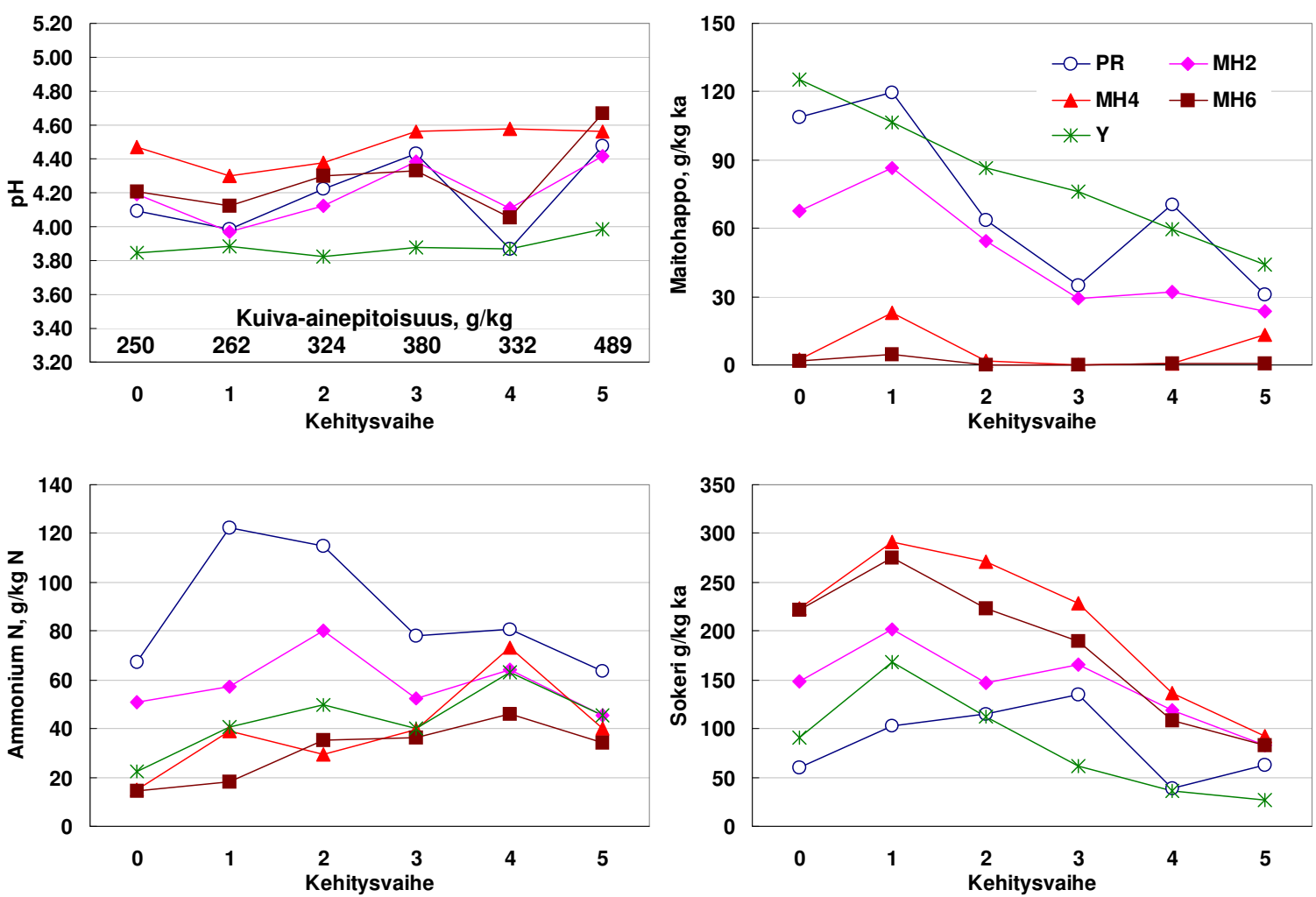

Kuva 1. Vuoden 2005 kokoviljasäilörehujen käymislaatu 6 kk säilönnän jälkeen.
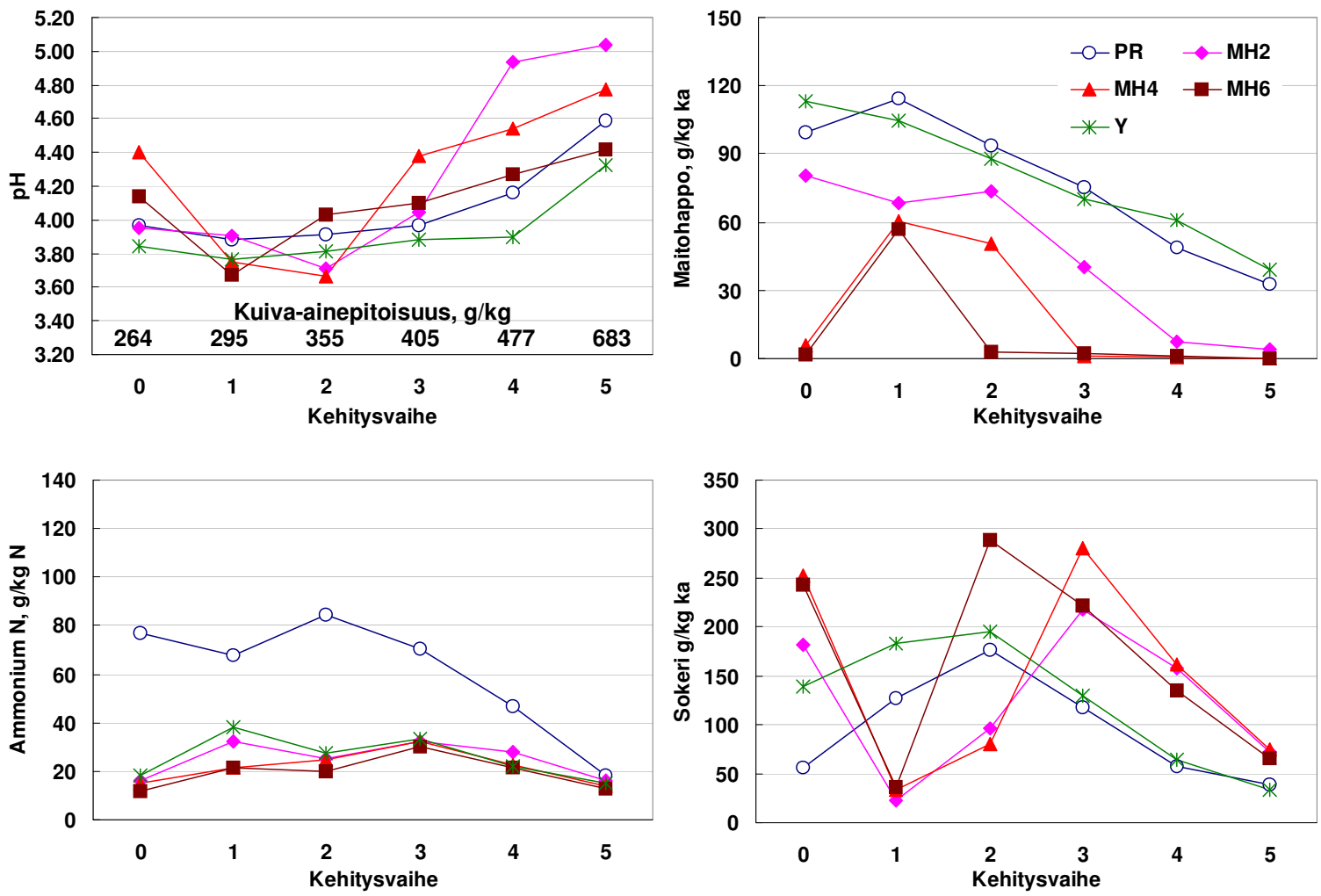

Kuva 2. Vuoden 2006 kokoviljasäilörehujen käymislaatu 6 kk säilönnän jälkeen 